Cahiers $d u$ MONDE RUSSE

\section{Cahiers du monde russe}

Russie - Empire russe - Union soviétique et États indépendants

48/2-3 | 2007

Les résonances de 1905

\title{
Russkaja revoljucija 1905-1907gg. I ital'janskie levye
}

\author{
Valerij P. LJUBIN
}

\section{OpenEdition}

\section{Journals}

Édition électronique

URL : https://journals.openedition.org/monderusse/9017

DOI : 10.4000/monderusse.9017

ISSN : $1777-5388$

\section{Éditeur}

Éditions de l'EHESS

\section{Édition imprimée}

Date de publication : 15 avril 2007

Pagination : 441-448

ISBN : 978-2-7132-2147-7

ISSN : $1252-6576$

Référence électronique

Valerij P. LJUBIN, «Russkaja revoljucija 1905-1907gg. I ital'janskie levye », Cahiers du monde russe [En ligne], 48/2-3 | 2007, mis en ligne le 01 janvier 2007, consulté le 04 septembre 2022. URL : http:// journals.openedition.org/monderusse/9017; DOI : https://doi.org/10.4000/monderusse. 9017 
chercher : repérer : avancer

Cet article est disponible en ligne à l'adresse :

http://www.cairn.info/article.php?ID REVUE=CMR\&ID NUMPUBLIE=CMR 482\&ID ARTICLE=CMR 4820441

\title{
Russkaj a revolj ucij a 1905-1907gg. I ital' janskie levye
}

\author{
par Valerij P. LJUBIN
}

\section{Editions de l'EHESS | Cahiers du monde russe}

\author{
$2007 / 2-3-$ Vol 48 \\ ISSN 1252-6576 | ISBN 9782713221477 | pages 441 à 448
}

Pour citer cet article :

-P. LJUBIN V., Russkaj a revoljucija 1905-1907gg. I ital' j anskie levye, Cahiers du monde russe 2007/ 2-3, Vol 48, p. 441-448.

Distribution électronique Cairn pour les Editions de l'EHESS.

(C) Editions de l'EHESS. Tous droits réservés pour tous pays.

La reproduction ou représentation de cet article, notamment par photocopie, n'est autorisée que dans les limites des conditions générales d'utilisation du site ou, le cas échéant, des conditions générales de la licence souscrite par votre établissement. Toute autre reproduction ou représentation, en tout ou partie, sous quelque forme et de quelque manière que ce soit, est interdite sauf accord préalable et écrit de l'éditeur, en dehors des cas prévus par la législation en vigueur en France. Il est précisé que son stockage dans une base de données est également interdit. 


\section{ВАЛЕРИЙ П. ЛЮБИН}

\section{РУССКАЯ РЕВОЛЮЦИЯ 1905-1907 ГГ. И ИТАЛЬЯНСКИЕ ЛЕВЫЕ}

После первой русской революции хх века в 1905 г. в России полосы революционных потрясений сменяли периоды контрреволюционных откатов, а приходившие к власти деятели не раз пытались коренным образом реформировать страну. Не последними причинами революции 1905 г. стали вопиющие несоответствия достигнутого уровня экономического и культурного развития сохранявшимся обветшалым политическим структурам традиционного самодержавия и неспособность правящих классов провести преобразования. В многонациональном государстве остро встал и вопрос требовавших для себя больших прав и самостоятельности национальных окраин. Этот вопрос завел Российскую империю в тупик и стал одной из причин двух революций 1917 г., а в 1991 г. - одной из причин развала ее наследника - Советского Союза. Осознание масштаба проблем, вызывающих революцию, и соответствующие своевременные действия по их решению - показатель способности правящих слоев к проведению реформ, позволяющих избежать революционных потрясений.

Первая русская революция 1905-1907 гг. получила отклик во всем мире, и прежде всего в странах Европы. С особым, напряженным вниманием за событиями русской революции следили в Италии. Особенно острой была реакция итальянских левых и в первую очередь социалистов. Об этом свидетельствуют архивные документы, в большинстве своем остающиеся неопубликованными и не введенными в научный оборот. Данная статья базируется преимущественно на архивных материалах, главным образом донесениях российских послов в Риме, хранящихся в Архиве внешней политики Российской империи (АВПРИ).

Документы российского посольства в Риме начала хх века позволяют увидеть Италию того времени глазами царских дипломатов, выявить, как

\footnotetext{
* На основе доклада на международной научной конференции «Забытая революция» в Москве в октябре 2005 г. О влиянии революционных событий в России 1905-1907 и 1917 гг. на Италию и итальянское рабочее и социалистическое движение в целом более подробно см.: В.П. Любин, Социалисты в истории Италии. ИСП и ее наследники, 1892-2006. М.: Наука, 2007, с. 104-259.
} 
итальянцы, прежде всего представители левых партий, реагировали на революционные волнения в России. Донесения регулярно читал Николай II, на них сохранились его пометки. Мнения дипломатов брались в расчет царем и его политическим окружением, оказывали воздействие на формирование политики в отношении Италии. Царь и его окружение воспринимали известия с Апеннин вовсе не беспристрастно. Именно в это время должен был состояться ответный государственный визит Николая II в Италию. Россия, как и динамично развивавшаяся объединенная Италия, достигшая заметных успехов в современных отраслях индустрии: автомобилестроении, электроэнергетике, судостроении, химическом производстве, была заинтересована в интенсификации торгово-экономических отношений. Но ввиду антицаристских настроений в Италии из-за негативного отношения итальянских демократических сил к кровавым событиям в России, о чем с досадой сообщали русские дипломаты, визит царя долго откладывался. Благоприятные условия возникли много позже, и он состоялся лишь в 1909 г.

Неспокойно было в те годы и в самой Италии. Укреплялись позиции социалистов, радикалов и демократов-республиканцев находившихся в непримиримой оппозиции к Савойской монархии и королевскому правительству. Представители этих трех партий получили название Крайней левой - Estrema sinistra. Социалисты представляли на политической арене интересы быстро растущего рабочего класса, остававшегося, по наблюдению французского историка П. Мильца, в начале хх века «среди наиболее плохо оплачиваемых в Европе и имевшего один из самых продолжительных рабочих дней» ${ }^{1}$. Кроме того, в стране продолжали действовать террористы анархисты. В 1900 г. от руки анархиста погиб король Умберто I. Новый король ВикторЭммануил III, остававшийся на троне до конца Второй мировой войны, сменил внутриполитический курс на менее жесткий. В начале хх в. пост премьерминистра не раз занимал левый либерал Джолитти. Он проводил либеральный курс наподобие курса Ллойд-Джорджа в Англии, его политика была направлена и на улучшение положения трудящихся классов. В поисках установления социального мира Джолитти был готов допустить к власти оппозиционные силы, в их числе социалистов, предлагал им войти в правительство. Как раз в начале 1905 г., когда в России началась революция, он провел успешную политическую рокировку и в итоге внеочередных парламентских выборов остался у власти.

«Правительство г-на Джолитти сумело в ходе последних выборов оказать противодействие поднимающемуся морю анархии» ${ }^{2},-$ вычурно писал по-французски министру иностранных дел Ламздорфу в Петербург из Рима временно поверенный в делах, консервативно настроенный царский дипломат А. Крупенский. И добавлял

1. P. Milza, Storia d'Italia. Dalla preistoria ai giorni nostri, Milano: Corbaccio, 2006, p. 759. Первоначальное издание на французском языке: Idem, Histoire de l'Italie, P.: Fayard, 2005.

2. Архив внешней политики Российской империи (далее: АВПРИ), фонд 133 (Канцелярия МИД), 1905, д. 105, л. 101. Крупенский - Ламздорфу. Датированное: Rome, le 22 Janvier / 4 Fevrier 1905 телеграфное донесение получено 26 января по ст. стилю, на нем имеются карандашные пометки царя. 
в постскриптуме: «Заместитель министра иностранных дел в момент, когда я запечатьвал донесение, просил меня передать Вашему Сиятельству, что “г-н Титтони [бывшийв тотмоментодновременноминистроминостранныхивнутренних дел в правительстве Джолитти - В.Л.] дал решительный и недвусмысленный ответ на запрос по поводу Максима Горького [арестованного и находившегося тогда в Петропавловской крепости. - В.Л.] и событий в Петербурге“»³.

В отправленном в тот же день другом донесении Крупенский констатировал, что среди арестованных в Санкт-Петербурге «пользуется особенною симпатиею за границею Максим Горький, сочинения которого переведены на итальянский язык». В Риме по примеру других стран образовался комитет в защиту Горького «под председательством члена Палаты, заседающего на крайне левой стороне, князя Сципиона Боргезе». На том же заседании Палаты министр иностранных дел был запрошен депутатами-социалистами Турати и Биссолати, считает ли он своей обязанностью довести до сведения императорского правительства, что «вся Италия глубоко возмущена петербургскими изуверствами»? На этот запрос Титтони «прямо отказался отвечать» и «вызвал этим шумные протесты, которым, однако, вмешательство председателя Палаты положило конец» ${ }^{4}$.

Действительно парламентский запрос Турати, Кабрини, Моргари, Косты, Биссолати и других депутатов левого крыла по поводу событий января 1905 г. в Петербурге был подан на заседании Палаты депутатов итальянского парламента 1 февраля 1905 г. во время обсуждения внешнеполитического курса страны. Они запрашивали министра Титтони, не намерено ли итальянское королевское правительство передать правительству царя, что «вся цивилизованная Италия» возмущена расправами в Петербурге . Вопрос о событиях в Петербурге был поставлен уже на предыдущем парламентском заседании 30 января 1905 г., тогда на него пришлось отвечать заместителю министра Ди Сант'Онофрио 6 . На заседании же 1 февраля произошла настоящая перепалка Биссолати с Титтони, который заявил о том, что он «выполняет свой долг» и «не может воспринять подобный запрос». Тем самым министр действительно отказался комментироватьповедениесвоегоправительстваотносительнорусских событий, и одновременно председатель Палаты отдал распоряжение стенографистам не записывать то, что говорит Биссолати․․ Тогда же поступил запрос депутата Поццати относительно положения, в котором находился писатель Горький

«Петербургские стачки и беспорядки, которые привели к вооруженному столкновению толпы с войсками, произвели в Италии, как и везде за границею, сильное впечатление»,- констатировал Крупенский. - «Нельзя отрицать,

3. АВПРИ, ф. 133. 1905. д. 105. л. 104.

4. Там же. л. 107.

5. Atti del Parlamento italiano. Camera dei Deputati. Legislatura XXII, 1904-1909. Discussioni, Vol. I, Roma, 1905. p. 724.

6. Ibid., p. 663-664.

7. Ibid., p. 724-725.

8. Ibid., p. 724. 
что чувство человеколюбия играло некоторую роль в сострадании здешнего населения к жертвам петербургской стачки», но, по мнению царского дипломата, «в сущности, симпатия эта главным образом напускная». «В ней выразилась общность целей всех недовольных и революционных элементов Европы, которые воспользовались этим удобным случаем для пропаганды своих разрушительных теорий.» ${ }^{9}$

Далее давалась более откровенная оценка отношения в Италии к расстрелу демонстрации рабочих на Дворцовой площади и последующим событиям. Дипломат вынужден был признать «сочувствие народонаселения к убитым рабочим, число которых было неимоверно преувеличено в здешних органах печати». Неприязнь к России «выразилась в самой неприличной форме не только на улице, но и что знаменательнее, в стенах самого парламента», писал он ${ }^{10}$. При этом Крупенский ссылался на донесение от 13/26 января 1905 г. бывшего посла в Риме князя Урусова, который в начале 1905 г. был назначен на новое место службы в Вену (пост посла в Риме получил видный царский сановник Н. Муравьев ${ }^{11}$ ). Урусов сообщал, что «при чествовании памяти подвижников Итальянской революции республиканский депутат Мирабелли предложил послать приветствие русскому народу», борющемуся с опасностью для жизни за свободу. «При этом названный депутат возымел смелость выразиться о государе императоре в словах, которые мне не полагает передавать», - смущенно замечал Крупенский, прилагавший к своему донесению газетную вырезку, в которой освещались названные сюжеты ${ }^{12}$. Манифестации в поддержку русской революции проходили «почти во всех городах Италии», писал он. В Риме в последнее воскресенье по инициативе «официозной» газеты «Трибуна» была устроена многочисленная процессия, которой руководили радикальные депутаты. Полиция и войска не допустили кровопролития. Во время манифестации корреспондент газеты «Русь» Амфитеатров от имени русских либералов поблагодарил «римский народ за красноречивую демократию и за симпатии», и эти его слова «были встречены громкими рукоплесканиями», отмечал Крупенский ${ }^{13}$.

Уже в конце 1905 г. посол Муравьев с большой озабоченностью сообщал о появившемся в итальянской печати воззвании «по поводу совершающихся в России кровавых событий», хотя как дипломат постарался сгладить его звучание. Манифест вышел за подписью «17 сенаторов, 38 депутатов и 10 других членов римского общества», среди них были известные люди, «деятели самых разнородных положений и политических взглядов». Так итальянское общество отреагировало, в частности, на устроенные черносотенцами еврейские погромы в России. Посол цитировал воззвание
9. АВПРИ. ф. 133. 1905. д. 105. л. 105.
10. Там же, л. 105 об.
11. Среди полученных им от царя прямых инструкций было указание «поддерживать в итальянском правительстве надежду на посещение» Николаем II Италии; АВПРИ, ф. 133,1905 г, д. 105 , л. 15.
12. Там же, л. 105 об.
13. Там же, л. 106 об. 
в «близком переводе» и приводил такие высказывания его составителей: «Взволнованная Италия присоединяет свой голос к всеобему крику протеста против смертоубийств, которыми обагрена русская империя <...», или: «всевозможные избиения, повредившие великому русскому народу более, чем его военные неудачи [имелись в виду итоги русско-японской войны. - В.Л.], $<\ldots>$ горестно поражают всякого, в ком еще живо чувство взаимного единения людей». «Разделяя протестующее возмущение всего цивилизованного мира против свирепого преследования русских евреев, вся Италия, без различия религиозных, политических и социальных убеждений, в единодушном страдании за оскорбленное человеколюбие, осуждает страшные убийства, напоминающие о самых жестоких в истории заблуждениях» ${ }^{14}$. В воззвании недвусмысленно отразилось отношение части итальянской элиты к событиям в России 1905 г. Еще более резко действия царского режима осуждались представителями контрэлиты, деятелями находившегося в Италии в начале века на подъеме рабочего и социалистического движения.

Как отмечалось в итоговом документе российского МИДа о событиях 1905 года, в Италии в тот год правительству пришлось «стать лицом к лицу с рабочим движением, выразившемся всеобщею стачкою железнодорожных служащих». Благодаря, однако, осознанию правительством всей опасности забастовки и решимости «прекратить ее всеми имеющимися средствами, последняя продолжалась всего лишь пять дней». Отметим, что эта стачка вошла в историю, став родоначальницей такого известного во всем мире явления, как «забастовка по-итальянски» - бастующие железнодорожники начали скрупулезно выполнять положенные по инструкциям предписания, в результате страна оказалась на грани транспортного паралича.

Позднее, весной 1906 г. революционное брожение в Италии усилилось. Как доносил в Петербург Муравьев, после первомайских демонстраций с требованием установления в стране 8-часового рабочего дня, в Турине, Болонье, Флоренции, Генуе, Милане, Риме прошли манифестации с участием десятков тысяч рабочих. Им противостояла полиция, в результате было немало раненых, в стране нарастало массовое недовольство ${ }^{15}$. Были случаи, когда в Италии арестовывали русских революционеров, связанных с местными анархистами, готовившими взрывы бомб ${ }^{16}$.

17 мая было сформировано новое правительство Джолитти. В октябре 1906 г. в Неаполь из Америки прибыл «известный писатель Максим Горький», намеревавшийся прожить в Италии два-три месяца, замечал Муравьев. «Он принимает делегатов различных кружков и журналистов, которые затемпомещают в газетах разговоры с ним о России и русских делах.» По мнению посла, приезд писателя, популярного в Италии, мог дать повод «для неизбежных манифестаций и агитации, но едва ли будет иметь серьезное общественное значение, особенно если не обращать на него никакого официального внимания». Через месяц

\footnotetext{
14. Там же, л. 320.

15. АВПРИ, ф. 133, 1906, д. 120, л. 103-119.

16. Там же, л. 142.
} 
посол сообщал о напряженной обстановке, вызванной в частности взрывами, устроенными анархистами в Риме - у кафе «Аранчо» и в храме Святого Петра ${ }^{17}$.

Левые в Италии следили за развитием событий в России и давали свои комментарии. На одном из заседаний Палаты депутатов Биссолати дал оценку положению России на международной арене после русско-японской войны и разразившейся в стране революции. «Мы знаем, что после катастроф на полях сражений на Дальнем Востоке и ввиду своего внутреннего кризиса силы и влияние России подорваны и потому она не может серьезно угрожать АвстроВенгрии». Поэтому, заявил Биссолати, переходя уже к внешнеполитическому положению Италии и ее политике в отношении Австро-Венгрии, «значение Тройственного союза» для последней «сильно уменьшилось» ${ }^{18}$.

В те годы на заседаниях парламента итальянские левые, больше всего социалисты, полемизировали с руководителями правительства, особенно с Фортисом и Соннино, и их министрами и доказывали, как это не раз делал Турати, что в условиях, когда «один класс обладает всем, а другой ничем», «классовая борьба стала демиургом истории, одним из главных двигателей цивилизации и прогресса» ${ }^{19}$. Социалисты прекрасно осознавали, что в тех условиях им не найдется места в правительстве: «мы конечно же не надеемся стать министрами илизаместителями министров», поэтому можемговоритьс этой трибуны обо всем откровенно, заявил один из ведущих депутатов-социалистов Э. Ферри ${ }^{20}$. Вслед за Турати он отстаивал право рабочих на борьбу и защиту собственных интересов. Одним из первых он дал развернутую характеристику итальянского общества и разделения страны на множество Италий, от промышленного развитого Севера - от Лигурии до долины По, затем не слишком развитой центральной части страны, до Юга и островов с их застывшими структурами, для развития которых правительство, по его мнению, фактически ничего не делает. «Великая нация не может обрести стабильность, когда в одной части страны жизнь процветает, а другие обречены на паралич и смерть», заявил Ферри ${ }^{21}$.

Что касается развития внутриполитической обстановки в Италии и отношения общественного мнения к России, в начале 1907 г., посол Муравьев с тревогой писал, что «под влиянием внутриполитических событий в России, и в виду предстоящих выборов в Государственную Думу, в Италии появляются во множестве разнообразные», с его точки зрения, «неосновательные и по большей части враждебные императорскому правительству сведения о положении и ходе наших дел». В распространении таких сведений обвинялись петербургские корреспонденты газет «Tribuna» И «Corriere della sera» Г. Пардо и А. Альбертини. «Не говоря уже о злостных и явно клеветнических сообщениях, помещаемых в таких чисто еврейских органах, как миланский «Secolo» или крайних социалистических газетах, как «Avanti» (под псевдонимом Ивана

17. Там же, л. 255-256, 261-263.

18. Atti del Parlamento italiano..., Vol. IX. Roma, 1906. p. 11061.

19. Atti del Parlamento italiano..., Vol. V. Roma, 1905. p. 6012.

20. Ibid. p. 6360.

21. Ibid., p. 6361. 
Кирдецова), «Аzione» (Ивана Сазонова) и других»,- добавлял Муравьев. Недавний арест в Петербурге итальянских подданных Каффи и Левина, а также «несомненно, фантастические рассказы о пытках, которым подвергаются в России политические арестанты (в Риге и других городах) послужили поводом к целому потоку печатных нареканий на ,,русские ужасы и жестокости“»»22. Посол считал невозможным, да и едва ли нужным «предпринимать официально что-либо против подобного явления, естественного и неизбежного при здешней свободе печати и нынешнем ее настроении» ${ }^{23}$.

«Но главным центром агитации против нас, - продолжал посол, - сверх пресловутых конференций неутомимо странствующей по Италии Ангелики Балабановой являются все-таки русские-выходцы революционеры, которые группируются теперь вокруг имени и личности Максима Горького и пользуются покровительством и помощью итальянских социалистов.» «Горький, выставляемый чуть ли не заграничным главою русского революционного движения и приверженцем так называемых „максималистов“, продолжает в полном довольстве проживать на острове Капри, предается литературным занятиям, а вместе с тем принимает многочисленных посетителей и очень охотно играет роль „учителя““, к которому едут на поклонение и из любопытства. Недавно к нему присоединился его единомышленник писатель Леонид Андреев.» После того, как префект Неаполя Караччоло запретил представление в городе пьесы Горького «Дети солнца», этот спектакль удалось устроить в Салерно ${ }^{24}$. Горький обратился с манифестом к итальянскому народу, в котором он с «безграничным самомнением» благодарит итальянцев за гостеприимство, «превозносит русских революционеров и попутно в нескольких строках совершает настоящее оскорбление Величества», что, как считал Муравьев, «несомненно, заслуживает внимания властей при ожидаемом возвращении Горького в Россию» ${ }^{25}$.

На подъем революционного движения в Италии несомненно оказывали влияние известия, приходившие из сотрясаемой революционными конвульсиями России. Как сообщал посол, 14/27 января 1907 г. «римские социалисты <...> организуют собрание в публичной зале» на улице Марморелле для того, чтобы «ознаменовать воспоминание о петербургском „красном воскресении“ (domenica rossa), т.е. о 9 января 1905 года». Горького настоятельно просили председательствовать на этом митинге, но он, как послу о том передал министр внутренних дел, «предусмотрительноуклонился». «Пустьпоболтаютипокричат в четырех стенах, а на улицу мы их не пустим», заявил послу Джолитти «не без

22. Биссолати, продолжавший с большим интересом следить за развитием революционных процессов в России, внес в парламенте запрос об аресте и несправедливом приговоре итальянцам в России, и однажды поставил также вопрос о положении «русских депутатов» Государственной думы. Ibid., p. 2186, 18317, 19156-19164.

23. АВПРИ, ф. 133, 1907, д. 109, л. 3-5.

24. По поводу не мотивированного, по его мнению, запрета этой театральной постановки был внесен парламентский запрос депутата Мирабелли. См. Atti del Parlamento italiano..., Vol. X. Roma, 1907. p. 12053. На той же сессии парламента Турати произнес речь о нарушениях прав рабочих в Италии. Ibid. p. 12802.

25. АВПРИ, ф. 133, 1907, д. 109, л. 7. 
злорадной насмешки над социалистами, которых он имеет основание считать и личными своими врагами». К донесению прилагался итальянский текст горьковского «Манифеста к итальянцам» от 5 января 1907 г. Русский писатель взывал к «демократической Италии», где «свобода есть синоним моральной красоты», приветствовал итальянский пролетариат и «друзей социалистов» ${ }^{26}$.

Итальянские власти были настолько напуганы возможными революционными выступлениями масс, что запретили в 1907 г. первомайские демонстрации. Социалисты отреагировали на это раздраженно, сообщал российский посол. «30 мая в Палате депутатов Турати - глава „реформистов“, даровитый миланский депутат, обратился к премьеру с энергическим запросом по поводу сделанных им распоряжений», посчитав их «посягательством на гражданскую и личную свободу». «Джолитти отвечал очень твердо, ссылкою на закон о публичной безопасности <...>, дающий властям право не допускать на улицах и площадях сборищ, опасных для общественного порядка.» При этом он заявил, что «в последнее время в манифестациях рабочих и социалистов большая часть принадлежит к сброду тунеядцев, бродяг и мальчишек буйного поведения». «Что же до упомянутого в речи Турати приезда Горького на празднование 1 мая», то, с удовлетворением заключал Муравьев, «Джолитти не без остроумной иронии заметил, что такому талантливому и знаменитому писателю будет гораздо приличнее и приятнее показаться публике в каком-либо закрытом помещении, где-либо в зале, чем на улице, среди бушующей толпы». «Социалистические депутаты сильно пошумели и поспорили с министром, но Палата, а за нею и печать приняли его заявление весьма сочувственно и одобрительно.» Горький, по сведениям посла, только что объявлявший себя больным, отправился в Копенгаген и Англию для участия в «конгрессе русских революционеров ${ }^{27}$.

Процитированные документы позволяют выявить отношение в Италии в среде итальянских левых к бурным событиям первой русской революции. Царские дипломаты предстают из их донесений как люди консервативно настроенные, глубоко преданные самодержавию, симпатизировавшие правившим в Италии политикам, представлявшим традиционную аристократию и крепнущий слой богатых предпринимателей и, напротив, враждебно относившимся к итальянским социалистам и революционерам, отражавшим интересы трудящихся трудящихся. Приведенные мною, как и многие другие неопубликованные документы российских архивов, отражают не только интереснейшие факты и события, увиденные глазами их современников, но и помогают выявить глубинные тенденции, проявившиеся в начале хх в. и оказавшие заметное влияние на дальнейший ход европейской и мировой истории.

Отдел истории Института научной информации по общественным наукам Российской Академии наук (ИНИОН РАН)

\section{ljubin@inion.ru}

26. Там же, л. 3-9.

27. Там же, л. 128-132. 